\title{
The Problem and Countermeasure of Team Construction of Double-certificate Teachers in Vocational Colleges
}

\author{
Chui-Jiu LIU ${ }^{1, a}$ \\ ${ }^{1}$ Research Department of Chongqing Business Vocational College, Chongqing, China \\ ${ }^{a}$ cqszyzcp@163.com
}

Keywords: Double-certificate teacher, Construction, problem, Countermeasure.

\begin{abstract}
Since the proposal of establishing a teaching team excellent in teaching and morality, the amount of double-certificate teachers of vocational colleges has been increasingly enlarging. However, with the acceleration of urbanization and industrial modernization, the present double-certificate teachers' quality lags behind our development requirements. Due to the structural, mechanism and managing flaws, it is necessary to improve the team of double-certificate teachers of vocational colleges from the perspective of laws and regulations, evaluation and training mode.
\end{abstract}

\section{The team construction of double-certificate teachers in vocational colleges}

\section{The existing problems}

The structural imbalance of teaching staff. With the enlargement of enrollment scale and renewal of major and department, most vocational colleges are faced with throny difficulties, such as the structural imbalance of full-time teachers. In other words, there are much more young teachers than old ones and much more teachers with intermediate titles than those with advanced titles. In regarding to the structure of graduation schools, the overwhelming majority of teachers come from regular institutions of higher learning. Meanwhile, due to weak applied disciplines, the enhancement of teaching quality has been hindered to some extent.

The small amount of double-certificate teachers. As most vocational colleges originated from technical secondary schools with good conditions, there is a significant gap in the quantity and quality of double-certificate teachers. For them, the definition isn't clear enough, the policy support isn't strong enough, even the reform of teaching salary, training plan, teaching content and assessment has not reflected the priority principle. Therefore, there is a lack of evaluation, assessment and promotion mechanism proper for double-certificate teachers.

The unsound management mechanism of part-time teachers. Generally speaking, most of the part-time teachers own rich professional knowledge and operational capacity but do not have enough vocational training and teaching experiences. Meanwhile, due to their single teaching method and poor ability of teaching organization, their teaching effect is badly influenced. However, on account of the limited number of part-time teachers, their employment cannot be carried out in accordance with relevant requirement and standard. Thus the overall level and teaching quality cannot be improved further in vocational colleges.

\section{The management mechanism of double-certificate teachers.}

The lack of evaluation system. Firstly, the lack of professional title evaluation system. For the current title evaluation, there are no corresponding quantitative indexes for professional competence, practice and technique application which have hindered the formation and development of double-certificate teachers. Secondly, the lack of performance evaluation system. Because of outdated assessment mechanism, the contribution of double-certificate teachers cannot be measured accuratedly. Their importance and particularity haven't been realized in most vocational colleges.

The lack of human resources management system. Firstly, the entry procedures need to be standardized and systematized. Most vocational teachers graduated from regular institutions of higher learning or used to be technicians of scientific research institutions or enterprises. Due to the 
lack of scientific standards, professionals in short supply cannot be brought in while unneeded teachers squeezed themselves into the teaching staff of vocational colleges by underhand methods. The present personnel system and policy do not support the flow of enterprise talent to institutions, which impedes the vocational colleges' absorption of double-certificate teachers. Secondly, the entry criterion need to be standardized and systematized. Vocational teachers usually begin their teaching job after graduation. Without practical experiences in enterprises or factories, their teaching is adverse to the development of students' professional capability. Therefore, the employment of part-time double-certificate teachers will be an important method. Thirdly, the personnel management needs to be standardized and systematized. With solid theoretical basis and strong technical application capability, the double-certificate teachers are greatly popular in regular institutions of higher learning and big enterprises which has resulted in the outflow of teaching staff of vocational colleges.

\section{The professional training of double-certificate teachers.}

The blind of training spots. Judged from relevant documents, the double-certificate refers to the lecturer and technical titles, teaching theories and practical skills and social service achievements. Vocational teachers who have a title of lecturer and a professional certificate can be rated as double-certificate teachers. As a matter of fact, what the vocational teachers need is real professional experience.

The blocked training channels. For the present training documents and regulations, there is no necessary measure or policy which guarantees the training of vocational teachers. Due to the shortage of school funding and continuation funding, the construction of double-certificate teaching staff remains in a tight corner. Some vocational colleges endeavor to bring in double-certificate teachers from personnel market while they miss the development of their own teaching staff. In addition, some double-certificate teachers have teaching task as well as administrative work and thus it is difficult for them to make self-enhancement.

The lack of systematic integration.The training of double-certificate teachers in vocational colleges still remains in a primary stage in which there is no integral construction. The training is often focused on pre-job training and theoretical training while the post-job training and practical training are missed and the teachers' professional development hasn't incorporated into the overall planning of college. Meanwhile, the training channels and institutions are relatively limited. For some teachers, they have few chances for systematic training. Besides, the outdated training materials have also led to low efficiency and satisfaction of training.

\section{The countermeasure for the team construction of double-certificate teachers}

\section{To improve the laws and regulations for professional training of vocational teachers.}

To formulate laws and regulations for professional training and management. The entry standards and authentification criterion for double-certificate teachers should be formulated in accordance with Chinese reality. The laws and regulations of vocational teachers, including the management of teachers, training, funding, skill evaluation and teaching quality evaluation, should also be established and fulfilled.

To establish a special fund for the training of vocational teachers. In China, vocational education is always regarded as informal. Because of the shortage of financial and human resources, vocational colleges often find it difficult to attract excellent talents. With the national emphasis of technical talents, it is necessary to increase the capital investment to guarantee the team construction and promote the overall level and training quality of vocational double-certificate teachers. In other words, the essential teaching and research conditions, such as office, equipment, facilities, personnel and documents, should be achieved through the special fund for double-certificate teachers.

To construct a lifelong training system for vocational teachers. The vocational education is a positional education which is closely connected with social demands, and the training of vocational 
teachers should be throughout the whole career. As the current amount of double-certificate teachers is far from enough in China, their training system should include lifelong pre-job training, post-job training, and specialization.

To increase the financial investment and emphasize the team construction. Teachers are the main force of school development, and the double-certificate teachers are a special demand of vocational education. The competent departments of education should learn advanced experiences from home and abroad, take full consideration of talent demands of regional economy and under-developed areas, strive to develop further education of vocational teachers and increase investment of vocational education to guarantee the fund and policy for backbone teachers' training. The managing staff of vocational colleges should make sufficient study on curricula and majors and teachers, formulate criteria and standards for double-certificate teachers and carry out flexible learning system in order to give full play to their initiative and creativity and promote the efficiency of further education.

To improve the training mechanism and strengthen the planning and management of training. Firstly, to make full use of school resources and strengthen on-campus training of vocational teachers. The on-campus training can be conducted through methods, such as business competition, lecturer attending, special lecture, academic discussion and on-campus training base. Secondly, to establish a mechanism of regular further education and enterprise practice for teachers according to needs of specialty and courses. Under this mechanism, vocational teachers will go to enterprises, scientific research centers or national training bases for further study and training according to college development plan. Thirdly, to promote the deep collaboration of service and development between enterprises and colleges. To be exact, the collaboration contains the connection and cooperation between colleges and production and research departments of enterprise, the teachers' participation in enterprises' new product development, and employees or customers training. Thus, vocational teachers will keep in touch with latest science and technology and integrate them into teaching.

To adopt specific educational training and conduct diversified training. Judged from the current team construction of double-certificate teachers in vocational colleges, there are problems of school, teacher and society and thus the training should be diversified. Firstly, to encourage teachers' on-the-job training through which they will participate in the training and examination and improve knowledge structure and business capability. Secondly, to send teachers to training bases regularly. Vocational teachers will be selected and sent for intensive training and learning advanced teaching theories and managing mode according to the construction and planning of teaching staff. Thirdly, to conduct on-campus training. The pre-job training, scientific research and teaching assistant system will help to promote teachers' practical and research capability. Forthly, to strengthen the cooperation between college and enterprise. To be exact, the cooperation contains the efficient expansion of practical training bases, the teachers' regular practice in enterprises and the campus-apprentice system to improve teachers' application and innovative capability. Besides, vocational colleges can also support teachers to strive for the degrees of master and doctor to enhance professional theoretical level.

To establish a reasonable evaluation and encouragement mechanism. The reform of distribution system. At present, the workload distribution system is popular in most vocational colleges. It has positive effects for the distribution according to labour and the system of rewarding-the-diligent and punishing-the-lazy. However, the workload distribution hinders the enhancement of teaching quality and development of double-certificate teachers. For this special team, the policy should emphasize technique, practice and innovation. On the one hand, it is necessary to strengthen management and evaluation through high standards and strict requirements. On the other hand, double-certificate teachers should be given preferential political, living and workload treatment to encourage teachers' endeavor. Meanwhile, there should be corresponding policies and regulations in favor of outstanding talents.

The sound evaluation system. On the one hand, the work performance of double-certificate teachers should be evaluated periodically, and the evaluation will be connected with professional 
title, salary and subsiy, and position and promotion. On the other hand, the formulation of a scientific incentive mechanism is necessary. The importance and particularity of double-certificate teachers should be embodied in treatment under a relatively fair distribution system. For example, the establishment of incentive reward to encourage the standard-reaching double-certificate teachers or raise their course and position allowances. Meanwhile, they have priority in professional evaluation and have more chances of learning, visiting and study. All of these preferential policies are aiming at attracting more excellent talents to vacational education and promote the construction of double-certificate teaching staff. For double-certificate teachers with poor performance, they must finish special training before they take new teaching task.

The management system and talent pool. The management mode of teaching staff and the allocation mechanism of teaching resources should be formulated and fulfilled in accordance with industrial restructuring and school development and the principle of resources sharing. The reasonable allocation and efficient utilization of teacher resources should be promoted through cooperation and recruitment of part-time teachers. Meanwhile, it is necessary to integrate training and recruitment and construct a teaching body with full-time and part-time teachers. The college authorities should encourage teachers to participate in practice in enterprises, factories or country to acquire corresponding technical achievement or grading certificate. Engineers or technicians with teaching experiences and solid production techniques of enterprises should be introduced as full-time or part-time teachers.

In conclusion, it is necessary for vocational colleges to start from a longterm and practical point, preserve talent with policy and treatment and stablize the teaching staff in order to improve the training quality and promote the connotative development.

(Note: this thesis belongs to the periodical achievements of a special subject - How to Strengthening the Construction of Double-certificate Teachers, one of the special subjects of vocational education in 2013 for the twelfth five-years plan of Chongqing Institute of Education Sciences. No.2013-zj-115)

\section{References:}

[1]Lin Nan, The Specialization Training Mode of Vocational Teachers in China,Vocational \& Technical Education Forum. 5 (2006)33-35.

[2] Yu Qunying, On the Team Construction and Transformation of Double-certificate Teachers,Higher Education Exploration. 4 (2006)77-79.

[3]Liu Chujia, Li Zhixiong, The Existing Problms and Countermeasure of Vocational Teachers, China University Teaching. 8 (2009)77-79.

[4]Chen Mingming, The Development and Charateristics of Vocational Teachers,Education Research Monthly. 5 (2009)32-37.

[5]Zhang Junhua, Zuo Xianlan, The Connotation and Development of Vocational Teachers, Vocational \& Technical Education Forum. 21 (2008)15 -19.

[6]He Xia, The Breakthrough of Vocational Teachers' Career Plateau,Vocational and Technical Education. 11 (2009)70 - 72. 